\title{
A Procedure for Implementing Exploratory Mixed Methods Research into Dry Port Management
}

\author{
Jagan Jeevana, Yapa Mahinda Bandarab , Nurul Haqimin \\ Mohd Salleha, Abdulhafaz Ngahc, Rudiah Hanafiah ${ }^{a}$
}

Qualitative approach has become the main method of exploring significant dimensions in dry port research. Quantitative approach has also been employed to examine empirical evidence in this research area. The application of mixed methods has been proposed in the dry port research to provide a multidimensional insight into seaport research issues. This paper provides guidance on mixed method application in dry port research and demonstrates that the implementation of mixed methods research is capable of providing comprehensive results by integrating qualitative and quantitative results in a single research. The availability of different dimensions and alternative designs lends this approach wide applicability, facilitating the production of valid and reliable outcomes and ensuring high level of generalizability of dry port research.

\section{KEY WORDS}

$\sim$ Dry ports

$\sim$ Mixed methods

$\sim$ Grounded theory

$\sim$ Exploratory factor analysis

$\sim$ Malaysia

a. Universiti Malaysia Terengganu, Faculty of Maritime Studies

e-mail: jagan@umt.edu.my

b. University of Moratuwa, Department of Transport and Logistics Management e-mail: mahindab@uom.lk

c. Unversiti Malaysia Terengganu, Faculty of Business, Economics and Social Development e-mail: hafaz@umt.edu.my

doi: 10.7225/toms.v08.n02.001

This work is licensed under (cc) BY

\section{INTRODUCTION}

Research methods in maritime logistics and management are crucial for assisting researchers in the examination of interesting themes and topics in this particular area. In general, quantitative research has become more popular than qualitative research (Shi \& Li, 2017) because qualitative methods, which include surveys, interviews, questionnaires, observations (SIQO), conceptual, content, comparative and qualitative analysis (CCCQ) can not provide precise or practicable conclusions in a scientific manner. On the other hand, quantitative methods offer an advanced analytical technique for a comprehensive research outcome. Shi and Li (2017) have conducted thorough research on the types of methods applied in 1292 journal papers published between 2000 and 2014, which has shown that quantitative methods had been used in 951 papers, compared to 341 papers whose authors opted for the qualitative method. This trend shows that the application of quantitative methods has dominated maritime logistics and management research. However, some qualitative research is required, especially when following a new line of research in maritime logistics and management.

In addition, the issue of generalisability and transferability of quantitative and qualitative research has become an important contributing factor to the dominance of quantitative over qualitative research in maritime logistics and management. Castro and Nieri (2008) agree that the explanatory power of mixed methods in maritime research exceeds that of either the quantitative or qualitative approach used on their own. Hence, in this paper, the application, advantages and challenges of mixed 
methods will be explored in connection with research on dry ports. This paper is organised as follows: Section 2 provides an overview of research methods and their application in dry port research. Section 3 describes the application of mixed methods in Malaysian dry port research, consisting of qualitative and quantitative phases. Section 4 elaborates the strategy of mixing qualitative and quantitative results. The findings are recapitulated and discussed in Section 5.

\section{APPLICATION OF RESEARCH METHODS IN DRY PORT RESEARCH}

Recently, the integration of quantitative and qualitative methods has become the methodological trend in dry port research. The trend became highly noticeable in 2009-2018 in journal papers gathered from reliable sources, especially from prominent journals on maritime logistics and management. Those journals include Transport Policy, Maritime Economics \& Logistics, Research in Transportation Economics, Maritime Policy \& Management, Research in Transportation Business \& Management, Regional Studies, Journal of Transport Geography, Transportation Research Part C: Emerging Technologies, Journal of Coastal Research, The Asian Journal of Shipping and Logistics and Journal of International Logistics and Trade. Nevertheless, qualitative methods are used far more frequently in dry port research than quantitative methods. For example, some of the authors including $\mathrm{Ng}$ and Gujar, (2009); Garnwa et al. (2009); Roso and Lumsden, (2010); Cullinane and Wilmsmeier, (2011); Hanaoka and Regmi, (2011); Haralambides and Gujar, (2011); Do et al. (2011); Rodrigue and Notteboom, (2012); Beresford et al. (2012); Ng et al. (2012); Monios and Wilmsmeier, (2012); Padilha and Ng, (2012); Ng et al. (2013); Bask et al. (2014); Jeevan (2015); Li et al. (2015) and Nguyen and Notteboom, (2016) have employed qualitative approach in dry port research (see Table 1).

On the other hand, the use of quantitative method in dry port research is lagging behind the qualitative method. Owing to limited literature on dry port research, an emerging prospect in seaport systems, as well as to the dynamic environment of the maritime sector, there is little opportunity to use the quantitative method in this specific area, giving more room to qualitative research. Mixed methods research combines the elements of both qualitative and quantitative research approaches during data collection, analysis and inference for the broad purposes of breadth and depth of understanding and corroboration (Johnson et al., 2007, p. 123). Effectiveness is the main reason for the application of mixed methods research, since its output exceeds that of mono method studies (Onwuegbuzie \& Leech, 2004). The combination of insights and procedures from two different paradigms provides a more productive and effective solution resulting in a superior product (Johnson \& Onwuegbuzie, 2004).
It offers separate interpretations of identifiable qualitative and quantitative data, providing a more coherent and comprehensive output than either mono method (Tashakkori \& Creswell, 2007).

\section{MIXED METHODS RESEARCH IN MALAYSIAN DRY PORTS}

Mixed methods design consists of 4 main designs, namely: triangulation, embedded, explanatory and exploratory designs (Creswell \& Clark, 2007). Triangulation design concurrently collects qualitative and quantitative data, merges both sets of data and uses the outcome to address a research problem (Jick, 1979). Embedded design simultaneously collects qualitative and quantitative data, with one form of data supporting the other (Tashakkori \& Teddlie, 2003). In explanatory design, quantitative data are collected first, following which qualitative data are used to explain and elaborate quantitative results in detail (Creswell \& Clark, 2007). Exploratory design starts from qualitative data and then collects quantitative information. The aim of this design is to gather qualitative data to explore the phenomenon and follow up by using quantitative data to explain the relationships between the previous data (Creswell, 2008).

In this paper, the application of exploratory design in Malaysian dry port research is elaborated. The research questions include: RQ1(What are the roles and challenges of existing Malaysian dry ports in the container seaport system?) and RQ2 (What are the strategies for enhancing Malaysian dry port operations and further development?). These two research questions are answered in the qualitative phase. Then, an additional research question: RQ3 (Which influencing factors of Malaysian dry port operations are vital for container seaport competitiveness?) is answered in the quantitative phase. These three subsidiary research questions have been developed to answer the primary research question exploring the PRQ (In what way does dry port development in Malaysia contribute to the competitiveness of container seaports in the container seaport system?). The application of mixed methods does not imply that two types of data sets are literally mixed. The mixing strategy in mixed methods needs to be used from the beginning of research. Hence, all research questions have been answered in the qualitative phase and one validated in the quantitative phase.

The qualitative approach overcomes limitations described in literature dealing with the role, challenges and strategy of dry port development in container seaport systems. The quantitative approach validates results obtained using the qualitative method and analyses the influencing factors of Malaysian dry port operations to determine the impact of dry ports on seaport competitiveness. Qualitative method gives us a better understanding of the inner experience of participants, explores areas not yet thoroughly researched, discovers relevant 
Table 2.

Inductive and deductive phase.

\section{Stages \\ Phase \& approach \\ Input}

\section{Process}

\section{Output}

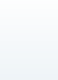

\section{Research approach}

Phase 1- Inductive

Interview with dry port operators, seaport authority and operators, and government bodies.

Grounded theory to identify the main theme of each section.

In-depth insight into the role of dry ports and the challenges faced in the container seaport system.

Identification of factors influencing dry port operations.

Platform established for

Phase 2 research.

\section{Phase 2- Deductive}

Compilation of online questionnaire and its distribution to dry port stakeholders.

Exploratory factor analysis for data validation.

Validation of factors influencing dry port operations.

Determining the correlation between dry port and seaport competitiveness.

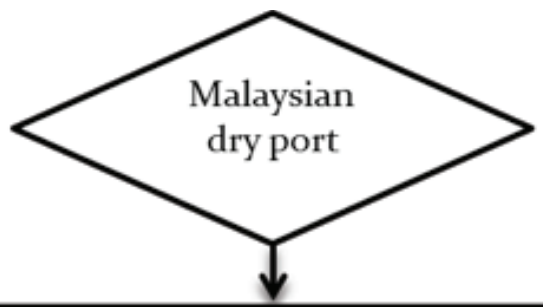

Phase 1: Qualitative method (Grounded Theory)

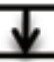

1. Role of dry ports in seaport system

2. Challenges, opportunity \& strategy for dry port development

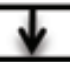

3. Influencing factors of dry port operations in the container seaport system and the implication for container seaport competitiveness.
Phase 2: Quantitative method (exploratory factor analysis)

Validation of the output (3) from qualitative phase in quantitative phase for the generalisation

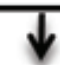

1. Influencing factors of dry port operations

2. Implication of dry port for the container seaport competitiveness

Development of Malaysian dry ports \& improvement in container seaports competitiveness level.

Figure 1.

Questionnaire mixing in mixed methods (Source: Authors). 
results of this phase have been analysed using grounded theory to answer the research question, with the additional output being the transition to the second phase.

Grounded theory was applied in the first phase of the research because it is the best approach to examining dry port operations in the Malaysian container seaport system. The limited amount of research suggests that the issue of dry ports has not been addressed in-depth, and provides only vague information on the emergence of dry ports in the container seaport system in Malaysia. In this respect, the research used grounded theory to arrive at clear conclusions on how dry port operators, seaports, policy makers and transport operators feel, think, and behave in the context relative to the two proposed secondary research questions. The grounded theory approach pursues generalisations by making comparisons across the social situation and has the capacity to encompass many different data and analytical perspectives with real-world problem solving (Corbin \& Strauss, 2008). This advantage, crucial for the research, ensures the integration of data from various stakeholders, including dry port operators, to provide a systematic approach to proposed secondary research questions.

During data analysis using grounded theory, five steps were followed to identify significant themes for each interview question (see Figure 2). First, familiarisation was used to immediately transcribe inputs and familiarise the researchers with the details. In the reflection stage, initial findings were compared with previous literature. Open coding and axial coding are the following steps. They involve the evaluation of transcript content to identify key concepts and establish how they are connected. Finally, selective coding, as the last procedure in grounded theory, aims to examine new findings by identifying frequent appearance of key words. During this stage, themes for SRQ1, 2 and 3 have been developed.

\subsection{Qualitative Data Analysis}

Questions asked in the interview sessions were divided into three main sections. The first section concerned the role of dry ports in the Malaysian seaport system. There were six questions in this section: the definition of dry ports, objectives and functions of dry ports, the clients of dry ports, inquiries into dry ports' operation and the benefits of the assistance of dry ports in managing cargoes transported to and from seaports. The second section examined the challenges faced by dry ports in the seaport system. The interview questions in the final section concerned the influencing operating factors of dry ports and consist of two main parts. The first part is about important factors contributing to the development of dry ports and seaport competitiveness.

According to Suddaby (2006), grounded theory is an interpretative process involving the researcher and the data. The usage of the qualitative software for data interpretation is not advisable because that software is incapable of detecting theoretical sensitivity, which is crucial in an interview session. Theoretical sensitivity is the ability to derive concepts from data to develop a theory. Theoretical sensitivity facilitates the formation of assumptions and knowledge structure from description to theoretical analysis (Parker \& Roffey, 1997). Theoretical sensitivity develops from professional experience, personal experience, knowledge and skills (Strauss \& Corbin, 1998).

\subsection{Bias Management Procedures for the Qualitative Phase}

Bias management throughout the research ensures the quality of the research. Typically, bias occurs during presentation and report writing (Creswell, 2013). During the qualitative phase data collection, the most important technique of bias minimisation is the establishment of rapport and trust with the respondents (Zikmund et al., 2010). Therefore, in this research, the respondents were contacted by telephone and email, which allowed the researchers to understand their social context before holding the interview. Apart from rapport establishment, several other, subsequent strategies have been implemented in the qualitative phase. The first is being ethical, especially during data analysis and the presentation of findings (Rudestam \& Newton, 2001). The researchers must not allow their personal experience, beliefs and judgements to affect the interviews. Moreover, the interview sessions were recorded for reference and final data integration (Creswell, 2013). Second, sensitive and offensive language must be avoided. For example, gender-biased words, suggesting judgements or reinforcing stereotypes are an undesirable category of expression (Rudestam \& Newton, 2001). Third, the use of appropriate research terminology and four interview and survey questions need to be pre-tested (Creswell, 2013). Finally, interview and online survey questionnaires need to be pre-tested to prevent any bias in the data collection procedure.

\subsection{Reliability and Validity of Qualitative Results}

First, the reliability of the qualitative phase was examined by establishing recording procedures for field notes (Kirk \& Miller, 1986). High reliability can be established by preparing four separate field notes, namely: a condensed account which contains the recordings of what happened, expanded account consisting of a log of events drawn up immediately after each interview session, the field work journal of cognitive experiences, such as ideas, emotions, mistakes and concerns noted during the interview session and finally a running record of interpretation drawn up during the interview (Kirk \& Miller, 1986).

The second reliability test in this phase was cross-checking. Cross-check coding was incorporated into this phase to improve 
reliability, since humans are prone to judgement errors (Franklin \& Jordan, 1997). Increasing reliability and coming up with new concepts or theories based on existing data sources are of key importance in this phase. During qualitative data analysis, crosschecking using various coding processes was implemented. Open coding, axial coding and selective coding were executed to improve the interpretation of data received from respondents and increase the reliability of output in this phase. Multiple crosschecks against existing literature were performed during coding sessions to devise a solid concept based on new findings.

Data reliability was improved by regularly checking the transcripts to ensure that they do not contain obvious mistakes made during transcription (Creswell, 2013). Transcripts were made after each interview session while the memory of the interview with the respondent was still fresh, to reduce the percentage of transcription mistakes. Once the text was transcribed, the transcript was re-checked several times to ensure data credibility.

To validate the results obtained in the qualitative phase, triangulation or purposeful sampling was implemented during the interview session. The triangulation technique is a cross-case analysis used for testing findings during the interview session (Reason \& Rowan, 1981). For example, in this study, dry port operators were asked about, e.g. the type of services provided by Malaysian dry ports, the facilities they currently have and the relationship of Malaysian dry ports with other seaports. After gathering the information from Malaysian dry port operators, dry port stakeholders or clients were asked the same questions. If the answers provided by different organisations to the same question are largely similar, the finding is highly trustworthy (Reason \& Rowan, 1981). The triangulation technique is the replication of

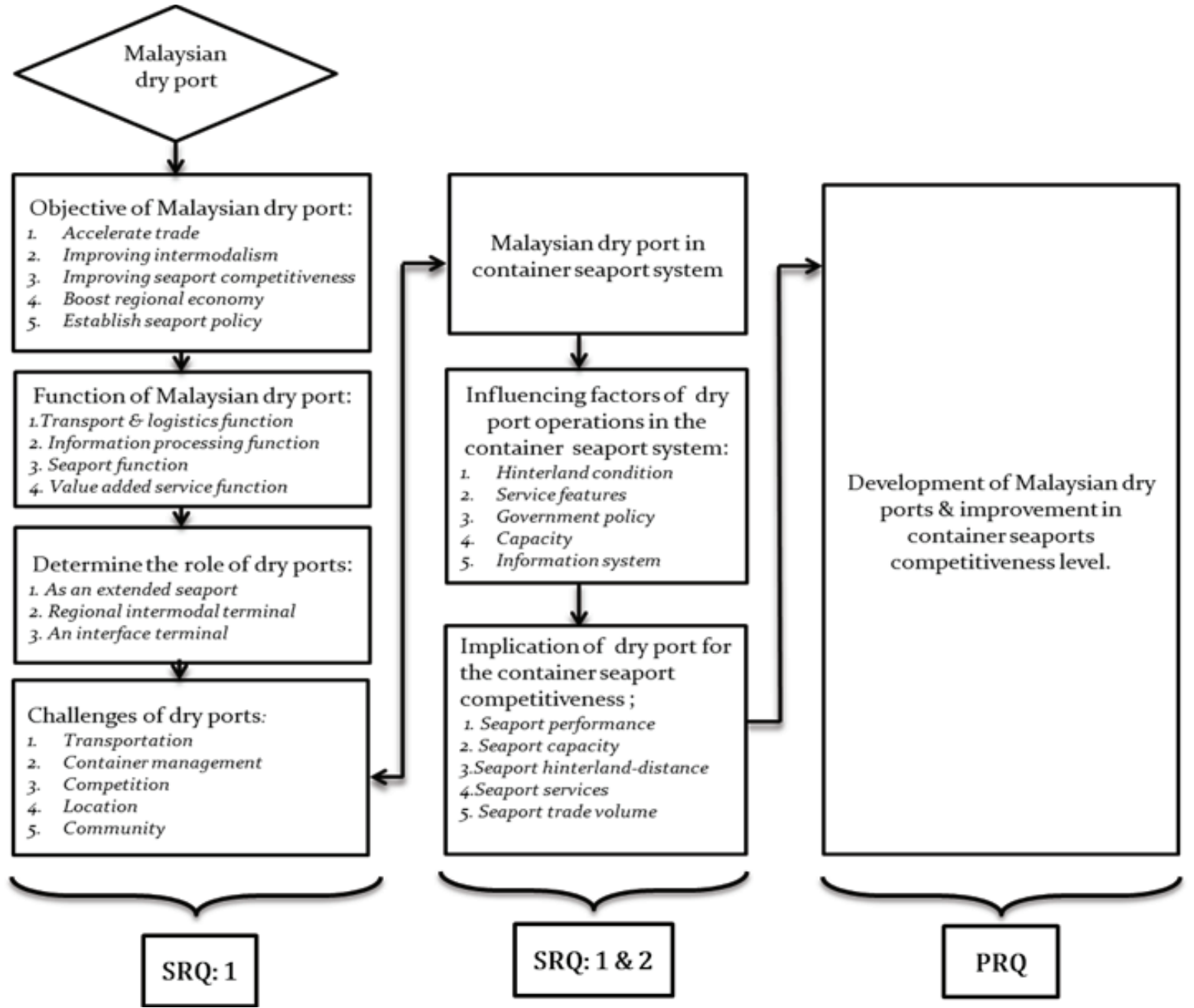

Figure 3.

Themes developed during grounded theory (Source: Authors). 
the finding using data collected from new participants, settings and events (Guba \& Lincoln, 1994). In this study, inputs from dry port operators, seaport authorities, seaport operators and governmental bodies were found to be largely similar during cross-case analysis.

Furthermore, reflexivity was used as a sequential test to verify the validity of qualitative data. Reflexivity is the ability to examine oneself (Padgett, 2009). During data gathering, open disclosure of preconceptions and assumptions may affect the output (Padgett, 2009). Thus, neither emotional struggle nor conflicts of interest must influence the researcher during the interview session, which reduces the biasness of results.

To ensure optimum validity of data collected in the qualitative phase, the members' checks technique was applied. At this point, all collected data were sent to participants of the research to obtain feedback. In qualitative research, feedback from participants helps validate the interpretation of the interview (Tutty, 1996). Next, spending prolonged time in the field is one of the methods of determining the validity of collected data, which allows the researcher to develop an in-depth understanding of the phenomenon. The greater the experience with the participants and the phenomenon, the higher the accuracy or validity of the findings (Creswell, 2013). Although allocated interview time is only 30-40 minutes, participants are motivated with additional questions, that prolong the interview to over an hour.

Transcripts were checked regularly to ensure that they did not contain obvious mistakes made during transcription (Creswell, 2013). The transcription was carried out after each interview session to draw on fresh memories of the interview with the respondent, to reduce the percentage of transcription mistakes. In addition, the transcripts were re-checked several times to improve data credibility. Figure 3 indicates the themes developed during grounded theory.

\subsection{Quantitative Phase}

The objective of the quantitative phase is to validate data on the dry ports' operating factors and their impact on competitiveness of Malaysian seaports. The sample for the quantitative phase was 170 respondents, selected among dry port stakeholders. The respondents came from a variety of groups, such as freight forwarders, shippers, shipping lines and hauliers, rail operators and seaports. They are the key players in dry port

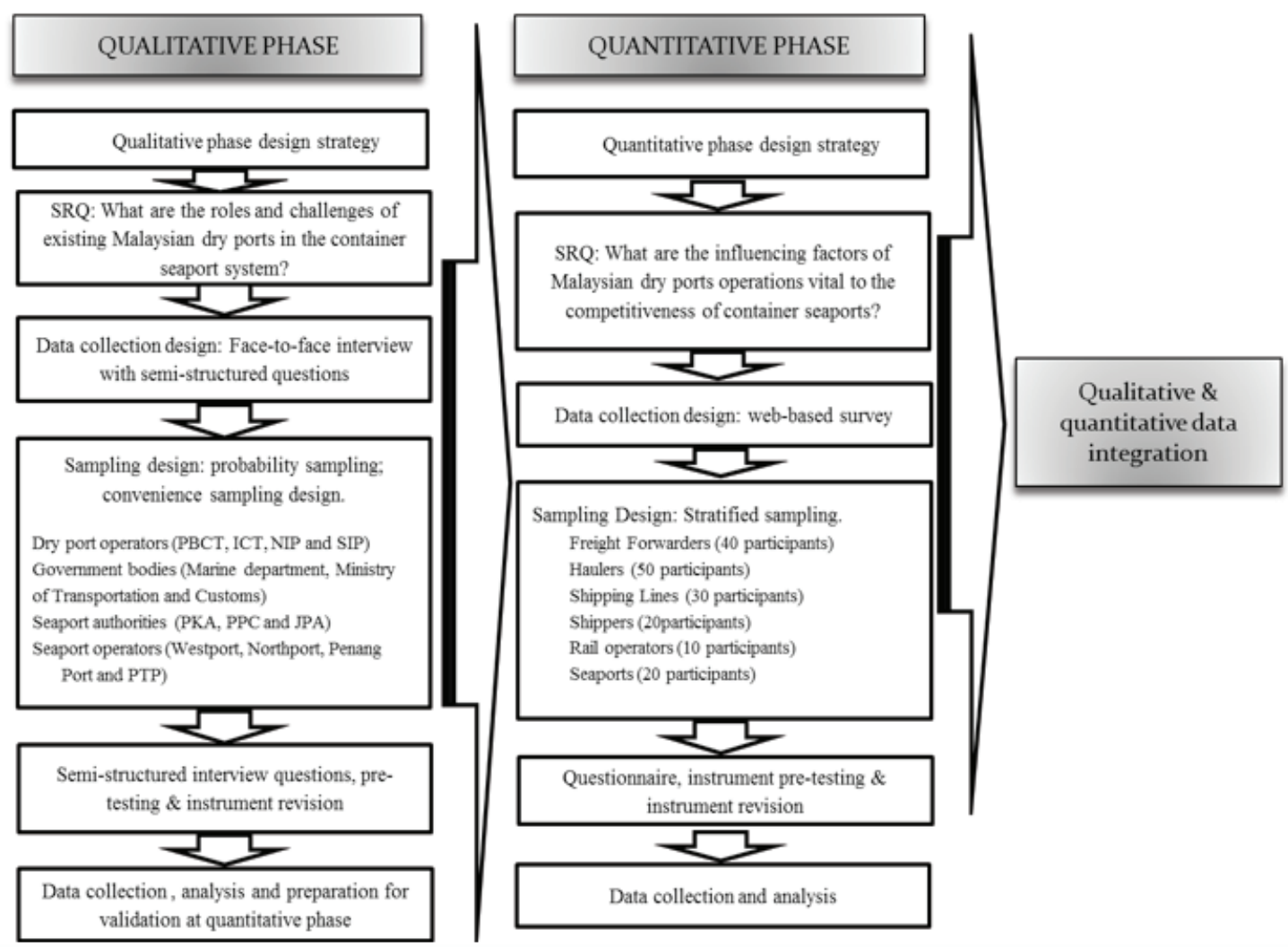

Figure 4.

The flow of mixed methods implementation (Source: Authors). 
operation and have a significant role in dry port operations in the seaport system (Roso \& Lumsden, 2010). The results obtained from this group refine and expand qualitative findings (Creswell, 2013). In this stage, online survey was chosen as means of questionnaire distribution. Stratified sampling was used to garner adequate data to analyse multiple subpopulations. It is an effective sampling strategy for studying the characteristics of a particular population, its points of view or standings on certain issues (Creswell, 2008).

In the quantitative phase, a mixture of descriptive and inferential statistical analysis was used by exploratory factor analysis (EFA). EFA is exploratory in nature and examines main dimensions to derive a concept, theory or model from a large set of items (Williams et al., 2010). In this research, EFA was used to validate and explore the correlations between the factors that influence Malaysian dry port operations and the impact of dry ports on seaport competitiveness. The objective of the second phase of the research was to evaluate these factors and construct a parsimonious description of the data structure. Both approaches are important for defining newly developing features or dimensions of factors that underline the set of items (Tabachnick \& Fidell, 2000). The nature of this research is mixed methods, focusing on exploratory sequential design and an application of EFA to validate the themes emerging from the constant comparison phase (Creswell \& Clark, 2007). According to Hurley et al. (1997), the EFA technique is suitable for factor exploration and evaluation compared to confirmatory factor analysis (CFA).

The initial exploration provided detailed and generalised results using the following quantitative analysis. The combination of qualitative and quantitative approach allows an exploration of views by listening to participants and following up with sequential questions to gain additional information on certain phenomena (Tashakkori and Teddlie, 2010). Figure 4 illustrates the research flow of two different methodologies integrated to provide answers to subsidiary research questions (SRQ). Meanwhile, the primary intention of the integration of data obtained in the qualitative and quantitative phases is to answer the primary research question (PRQ).

\subsection{Quantitative Data Analysis}

Statistical analysis of quantitative results was conducted using Statistical Package for Social Science software (SPSS) version 22.0. Analysis results were displayed in table, chart and graph form. However, the interpretations of the impact of dry port development on container seaport competitiveness have been derived by integrating data from both phases.

\subsection{Bias Management Procedures in the Quantitative Phase}

The application of EFA requires a bias analysis using Common Method Bias (CMB). Therefore, the common method bias has been conducted through Harman single factor analysis for using EFA, where all 42 variables loaded into a single factor. In any analysis, the newly introduced common latent factor accounts for over 50 percent of the variance indicating the presence of bias in the result (Eichhorn, 2014). However, in this research, the Common Method Variance (CMV) value was 27.015 percent and clearly indicates the absence of bias in the findings (see Table 3).

Table 3.

Outcome of CMV

Total Variance Explained

\begin{tabular}{lllllll}
\hline \multirow{2}{*}{ Component } & \multicolumn{2}{l}{ Initial Eigenvalues } & \multicolumn{3}{l}{ Extraction Sums of Squared Loadings } \\
\cline { 2 - 6 } & Total & $\%$ of Variance & Cumulative \% & Total & \% of Variance & Cumulative \% \\
\hline 1 & 14.048 & 27.015 & 27.015 & 14.048 & $\mathbf{2 7 . 0 1 5}$ & 27.015 \\
\hline 2 & 4.470 & 8.596 & 35.611 & & \\
\hline 3 & 3.465 & 6.663 & 42.274 & & \\
\hline $4 \ldots$ & 2.776 & 5.338 & 47.612 & & & \\
\hline
\end{tabular}

\subsection{Reliability and Validity of Quantitative Results}

In quantitative analysis, validity is measured to establish whether values obtained from the instruments are sensible, meaningful and whether the conclusions drawn from the sample studied are applicable to the population as a whole (Rudner, 2001). Reliability refers to the accuracy of a measurement procedure (Rudner, 2001). In EFA, several assumptions suggested by Pallant (2011), such as sampling adequacy, correlation coefficient and communality analysis were analysed to ensure 
the validity and generalisability of the output. The outcome from all assumptions shows that the results are valid and appropriate for generalisation. Content validity means that the questions represent all possibilities of questions available. Content validity was ensured by participants and academic professionals in pretesting, who commented especially on the content of the survey questions, the structure of the survey and the scale (Rudner, 2001).

The stability of the instrument was ensured by survey instrument pre-testing, or in this case the questionnaire. The stability of the instrument yielded almost identical results when the same instrument was repeatedly administered to the same samples at sufficient time intervals (Klassen et al., 2012). The stratification and optimisation of the entire data collection sampling frame enhance the internal consistency of quantitative phase data collection. Survey questions were based on literature and qualitative outcome. Moreover, literature covering studies on dry ports on other continents, such as Europe, Africa, America and some Asian countries was included. Hence, these procedures are a reflection of construct validity, external validity and generalisability of the quantitative phase. The coefficient-alpha is used for testing the reliability of internal consistency. The items scores are continuous variables, i.e. from "Strongly Agree" to "Strongly Disagree"; alpha provides the coefficient for estimating the consistency of values of an instrument. In the coefficientalpha test, the higher the score, the more reliable the generated scale in the questionnaire (Klassen et al., 2012). The acceptance coefficient value was indicated as 0.7 and above as acceptable (Garver et al., 2008).

\section{DATA MIXING OF QUALITATIVE AND QUANTITATIVE RESULTS}

The onset of the mixing stage in exploratory sequential design is not after the end of the study. Rather, the mixing stage starts during the development of qualitative and quantitative research questions in the early stage of the study. The combination of qualitative and quantitative research questions in a single study facilitates the inferential process in the interpretation stage (Tashakkori and Teddlie, 2003). The data integration strategy consists of the coherent presentation of data from both phases as shown in Figure 5 (Onwuegbuzie \& Teddlie, 2003). In mixed methods research, data integration is crucial for comparison, consolidation, infusion, building and embedding of qualitative phase results into and with quantitative phase results and vice versa to arrive at a new clarification and understanding (Teddlie \& Tashakkori, 2006). This process is critical for determining the quality of outcome in mixed methods research, which has been a significant advantage of these methods (Teddlie \& Tashakkori, 2003).

In this study, which employs exploratory sequential design, the mixing was made and connections established during the selection of participants for the quantitative follow-up analysis based on qualitative results. An additional connection point is a more detailed examination of phase one results by collecting and analysing the quantitative data in the second phase (Creswell \& Clark, 2011). The connection, mixing and inference have been conducted prior to the interpretation stage, meaning

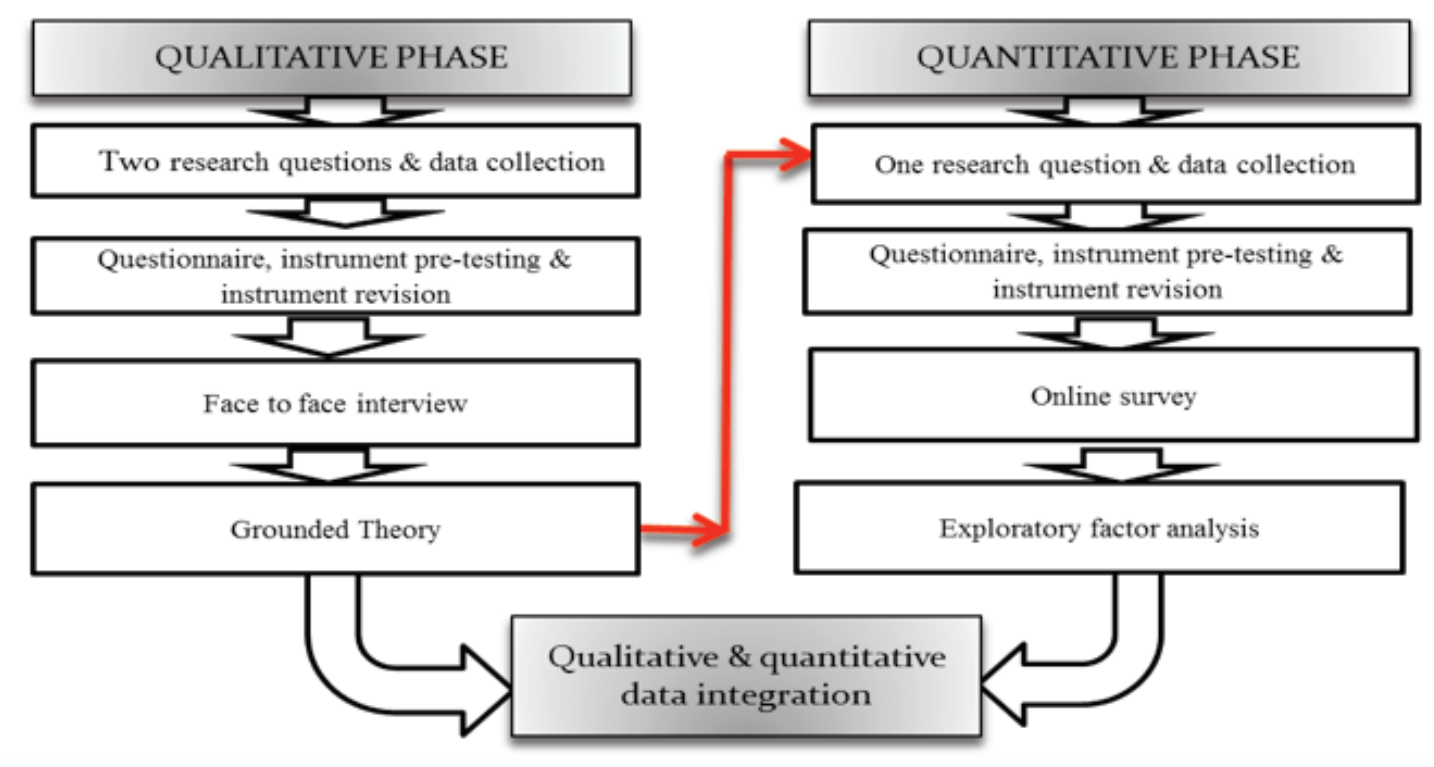

Figure 5.

Data integration in mixed methods research (Source: Authors). 
the utilisation of mixed methods research. Hence, this research contributes by demonstrating a manner of mixing qualitative and quantitative data.

Innovative design should be incorporated in the mixed methods research design process (Creswell \& Clark, 2011). The innovation in the design of mixed methods research in this study is that the advantages of both approaches were exploited to address the primary research question in-depth and ensure the generalisability of research results.

Although mixed methods research does have significant benefits, it is more labour intensive, requires extensive resources and its execution takes considerable time. Semi-structured faceto-face interviews were used to obtain more comprehensive and complex data, but the majority of respondents were reluctant to provide particular important and additional data that they considered confidential, which might have opened a wide scope in the research had they been revealed. Moreover, researcher's bias may have been present in the qualitative phase, during data collection and analysis. To overcome this bias, distance from the interviewees was maintained to prevent them being influenced by any beliefs or judgements of the researcher.

Secondly, the use of online survey may have limitations with respect to coverage, dependence on software and uncertainty about the identity of respondents in the survey (Sue \& Ritter, 2007). However, these preconceptions are unjustified because online surveys may produce reliable and quality data (Gosling et al., 2004). Limited by time frame, resources and geographical factors, online survey was used due to its flexibility and high accessibility to dry port stakeholders in Peninsular Malaysia.

Thirdly, sampling approaches applied in both phases of the research may have limitations. Since dry ports, seaports and other stakeholders are geographically scattered across peninsular Malaysia, their identification and accessibility were huge challenges in both phases. In the qualitative phase, a convenience sampling strategy was adopted to identify respondents meeting the required criteria and then choosing them on the first-come-first-chosen basis until the sample size was reached. Unfortunately, some respondents who had agreed to participate withdrew at the last minute due to unavoidable reasons. To reduce the risk of missing interviews with informationrich respondents, interview sessions were held in their own preferred venue and time. The interview sessions were continued until data reached the saturation stage, and similar answers to related topics were obtained.

A list-based stratified sampling strategy was used in the second phase. The ability to control the sampling was an important factor, since low internet speed, multiple responses and false identities could have an impact on the quality of the research outcome. Therefore, a list-based stratified sampling developed to control the situation. The goal of this type of sampling is to increase the number of potential participants of this phase. Sampling control at this stage became important due to the difficulty locating appropriate samples, since the goal of the research involved two major specifications - dry port development and container seaports competitiveness. Since the respondents who participated in this phase were stakeholders who keenly used dry ports, they had to be closely inspected before becoming our respondents. Moreover, this sampling strategy was also intended to increase the number of respondents in order for the results to be applicable to the wider population (Wilkinson \& Thornton, 1999).

Limited number of professional personnel capable of giving strategic insights into dry ports limited the number of respondents in the quantitative phase. Therefore, generalisability was ensured by developing a competent quantitative phase survey instrument based on the results of face-to-face interviews and relevant literature on dry port operations and container seaport competitiveness. The combination of these steps helped increase the study's scope and generalisability, because the mixed methods strategy contributed to the reliability and validity of the outcome, as the strengths of one phase countered the weaknesses of the other.

A dry port is still a new and emerging area in maritime logistics. Hence, the application of mixed methods research is suitable for the examination and validation of research results, especially in dry port research. Although the qualitative method was used in most of the literature, mixed methods can provide significant outcomes and are suitable for generalisation. Hence, mixed methods are suitable for studying an emerging issue in any area and then producing a concrete justification based on empirical evidence.

The main problem with mixed methods is data mixing. The mixing stage needs to start at the beginning, especially during PRQ and SRQ development, continue to be applied during the application of two different, mutually connected instruments, as well as during data collection from a single population and during data interpretation. This will ensure the relevance and generalizability of data obtained by mixed methods research.

\section{REFERENCES}

Ng, A.K.Y., Padilha, F. \& Pallis, A.A., 2013. Institutions, bureaucratic and logistical roles of dry ports: the Brazilian experiences. Journal of Transport Geography, 27, pp.4655. Available at: http://dx.doi.org/10.1016/j.jtrangeo.2012.05.003.

Ambrosino, D. \& Sciomachen, A., 2014. Location of Mid-range Dry Ports in Multimodal Logistic Networks. Procedia - Social and Behavioral Sciences, 108, pp.118-128. Available at: http://dx.doi.org/10.1016/j.sbspro.2013.12.825.

Bask, A. et al., 2014. Development of seaport-dry port dyads: two cases from Northern Europe. Journal of Transport Geography, 39, pp.85-95. Available at: http:// dx.doi.org/10.1016/j.jtrangeo.2014.06.014.

Bazeley, P. \& Kemp, L., 2011. Mosaics, Triangles, and DNA. Journal of Mixed Methods Research,6(1), pp.55-72. Available at: http://dx.doi.org/10.1177/1558689811419514. 
Beresford, A. et al., 2012. A study of dry port development in China. Maritime Economics \& Logistics, 14(1), pp.73-98. Available at: http://dx.doi.org/10.1057/ mel.2011.17.

Bryman, A., 2008. Of methods and methodology. Qualitative Research in Organizations and Management: An International Journal, 3(2), pp.159-168. Available at: http://dx.doi.org/10.1108/17465640810900568.

Castro, F. G. \& Nieri, T., 2008. Culturally-sensitive research: Emerging approaches in theory, measurement and methods for effective research on acculturation, ethnic identity and gender. Workshop conducted at the meeting of the Society for Social Work Research, Washington, DC.

Corbin, J. \& Strauss, A., 2008. Basics of Qualitative Research (3rd ed.): Techniques and Procedures for Developing Grounded Theory. Available at: http://dx.doi. org/10.4135/9781452230153.

Crainic, T.G. et al., 2015. Modeling dry-port-based freight distribution planning. Transportation Research Part C: Emerging Technologies, 55, pp.518-534. Available at: http://dx.doi.org/10.1016/j.trc.2015.03.026.

Creswell, J. W. \& Clark, L. P., 2007. Designing and conducting mixed methods research, 1st edition, Thousand Oaks, California: SAGE publication, USA.

Creswell, J. W., 2008. Educational research: Planning, conducting and evaluating quantitative and qualitative research, 3rd edition, Kevin M. Davis, New Jersey.

Creswell, J. W. \& Clark, L. P., 2011. Designing and conducting mixed methods research, 2nd edition, Thousand Oaks, California: SAGE publication., London.

Creswell, J. W., 2013. Research design: Qualitative, quantitative, and mixed methods approaches, SAGE publication, New Jersey.

Cullinane, K. \& Wilmsmeier, G., 2011. The Contribution of the Dry Port Concept to the Extension of Port Life Cycles. Handbook of Terminal Planning, pp.359-379. Available at: http://dx.doi.org/10.1007/978-1-4419-8408-1_18.

Do, N.-H., Nam, K.-C. \& Le, Q.-L.N., 2011. A consideration for developing a dry port system in Indochina area. Maritime Policy \& Management, 38(1), pp.1-9. Available at: http://dx.doi.org/10.1080/03088839.2010.533712.

DuBrin, A. J., 2003. Essentials of Management, 6th edition, Thomson South-Western, Peterborough, Ontario.

Eichhorn, B.R., 2014. Common method variance techniques. Cleveland State University, Department of Operations \& Supply Chain Management. Cleveland, $\mathrm{OH}$ : SAS Institute Inc.

Franklin, C., and Jordan, C., 1997. Qualitative approaches to the generation of knowledge, social work research and evaluation: Quantitative and Qualitative Approaches, Peacock Publishers, Illinois.

Garnwa, P., Beresford, A. and Pettit, S., 2009. Dry ports: a comparative study of the United Kingdom and Nigeria. Development of Dry Ports, 40.

Garver, M.S., Williams, Z. \& Taylor, G.S., 2008. Employing latent class regression analysis to examine logistics theory: an application of truck driver retention. Journal of Business Logistics, 29(2), pp.233-257. Available at: http://dx.doi. org/10.1002/j.2158-1592.2008.tb00094.x.

Gosling, S.D. et al., 2004. Should We Trust Web-Based Studies? A Comparative Analysis of Six Preconceptions About Internet Questionnaires. American Psychologist, 59(2), pp.93-104. Available at: http://dx.doi.org/10.1037/0003-066x.59.2.93.

Guba, E.G. and Lincoln, Y.S., 1994. Competing paradigms in qualitative research. Handbook of qualitative research, 2(163-194), p.105.
Hanaoka, S. \& Regmi, M.B., 2011. Promoting intermodal freight transport through the development of dry ports in Asia: An environmental perspective. IATSS Research, 35(1), pp.16-23. Available at: http://dx.doi.org/10.1016/j.iatssr.2011.06.001.

Haralambides, H. \& Gujar, G., 2011. The Indian dry ports sector, pricing policies and opportunities for public-private partnerships. Research in Transportation Economics, 33(1), pp.51-58. Available at: http://dx.doi.org/10.1016/j.retrec.2011.08.006.

Henttu, V. \& Hilmola, O.-P., 2011. Financial and environmental impacts of hypothetical Finnish dry port structure. Research in Transportation Economics, 33(1), pp.35-41. Available at: http://dx.doi.org/10.1016/j.retrec.2011.08.004

Hurley, A. E., Scandura, T.A., Schriesheim, C.A., Brannick, M.T., Seers, A., Vandenberg, R.J. and Williams, L.J., 1997. Exploratory and confirmatory factor analysis: Guidelines, issues, and alternatives. Journal of Organizational Behaviour, 18(6), pp. 667-683. Available at: https://doi.org/10.1002/(sici)1099-1379(199711)18:6\%3C667::aidjob874\%3E3.0.co;2-t.

Jeevan, J., Chen, S. \& Lee, E., 2015. The Challenges of Malaysian Dry Ports Development. The Asian Journal of Shipping and Logistics, 31(1), pp.109-134. Available at: http://dx.doi.org/10.1016/j.ajsl.2015.03.005.

Jeevan, J., Chen, S.-L. \& Cahoon, S., 2018a. Determining the influential factors of dry port operations: worldwide experiences and empirical evidence from Malaysia. Maritime Economics \& Logistics, 20(3), pp. 476-494. Available at: http://dx.doi. org/10.1057/s41278-017-0063-y.

Jeevan, J., Chen, S.-L. \& Cahoon, S., 2018. The impact of dry port operations on container seaports competitiveness. Maritime Policy \& Management, 46(1), pp.423. Available at: http://dx.doi.org/10.1080/03088839.2018.1505054.

Jick, T.D., 1979. Mixing Qualitative and Quantitative Methods: Triangulation in Action. Administrative Science Quarterly, 24(4), p.602. Available at: http://dx.doi. org/10.2307/2392366

Johnson, R.B., Onwuegbuzie, A.J. \& Turner, L.A., 2007. Toward a Definition of Mixed Methods Research. Journal of Mixed Methods Research, 1(2), pp.112-133. Available at: http://dx.doi.org/10.1177/1558689806298224.

Kirk, J. \& Miller, M., 1986. Reliability and Validity in Qualitative Research. Available at: http://dx.doi.org/10.4135/9781412985659.

Klassen, A.C. et al., 2012. Best practices in mixed methods for quality of life research. Quality of Life Research, 21(3), pp.377-380. Available at: http://dx.doi.org/10.1007/ s11136-012-0122-x

Li, Y., Dong, Q. \& Sun, S., 2015. Dry Port Development in China: Current Status and Future Strategic Directions. Journal of Coastal Research, 73, pp.641-646. Available at: http://dx.doi.org/10.2112/si73-111.1.

Monios, J. \& Wilmsmeier, G., 2012. Port-centric logistics, dry ports and offshore logistics hubs: strategies to overcome double peripherality? Maritime Policy \& Management, 39(2), pp.207-226. Available at: http://dx.doi.org/10.1080/03088839 2011.650720.

Monios, J. \& Wilmsmeier, G., 2012. Port-centric logistics, dry ports and offshore logistics hubs: strategies to overcome double peripherality? Maritime Policy \& Management, 39(2), pp.207-226. Available at: http://dx.doi.org/10.1080/03088839 .2011 .650720 .

$\mathrm{Ng}$, A.K. and Cetin, I.B., 2012. Locational characteristics of dry ports in developing economies: some lessons from Northern India. Regional Studies, 46(6), pp.757-773. Available at: https://doi.org/10.1080/00343404.2010.532117.

Ng, A.Y. and Gujar, G.C., 2009. Government policies, efficiency and competitiveness: The case of dry ports in India. Transport Policy, 16(5), pp.232-239. Available at: https://doi.org/10.1016/j.tranpol.2009.08.001 
Nguyen, L.C. and Notteboom, T., 2016. Dry ports as extensions of maritime deep-sea ports: a case study of Vietnam. Journal of International Logistics and Trade, 14(1), pp.65-88. Available at: https://doi.org/10.24006/jilt.2016.14.1.003.

Onwuegbuzie, A.J. \& Leech, N.L., 2004. Enhancing the interpretation of "significant" findings: The role of mixed methods research. The Qualitative Report, 9(4), pp.770792.

Onwuegbuzie, A. J. \& Teddlie, C., 2003. A framework for analysing data in mixed methods research, SAGE Publications, Los Angeles.

Pallant, J., 2011. SPSS survival manual: A step by step guide to data analysis using SPSS, Allen \& Unwin, New South Wales.

Padgett, D. K., 2009. Qualitative and mixed methods in social work knowledge development', Social Work, 52(4), pp.101-105. Available at: https://doi.org/10.1093/ sw/54.2.101

Padilha, F. \& Ng, A.K., 2012. The spatial evolution of dry ports in developing economies: The Brazilian experience. Maritime Economics \& Logistics, 14(1), pp.99121. Available at: https://doi.org/10.1057/mel.2011.18.

Parker, L.D. \& Roffey, B.H., 1997. Methodological themes. Accounting, Auditing \& Accountability Journal, 10(2), pp.212-247. Available at: http://dx.doi. org/10.1108/09513579710166730.

Reason, P. \& Rowan, J., 1981. Human inquiry. A sourcebook of a new paradigm research, Chichester, Wiley.

Rodrigue, J.P. and Notteboom, T., 2012. Dry ports in European and North American intermodal rail systems: Two of a kind? Research in Transportation Business \& Management, 5, pp.4-15. Available at: https://doi.org/10.1016/j.rtbm.2012.10.003.

Roso, V. and Lumsden, K., 2010. A review of dry ports. Maritime Economics \& Logistics, 12(2), pp.196-213. Available at: https://doi.org/10.1057/mel.2010.5.

Rudestam, K.E. \& Newton, R.R., 2001. Surviving your dissertation: A comprehensive guide to content and process, 2nd edn, Thousand Oaks, SAGE publication, CA.

Rudner, L. M., 2001. Informed test component weighting. Educational measurement: Issues and practice, 20(1), pp.16-19. Available at: https://doi. org/10.1111/j.1745-3992.2001.tb00054.x

Shi, W. \& Li, K.X., 2017. Themes and tools of maritime transport research during 2000-2014. Maritime Policy \& Management, 44(2), pp.151-169. Available at: https:// doi.org/10.1080/03088839.2016.1274833.

Strauss, A.\& Corbin, J., 1998. Basic of qualitative research:Techniques and procedures for developing grounded theory. 2nf edn, Thousand Oaks, SAGE publication, USA

Suddaby, R., 2006. From the Editors: What Grounded Theory is Not. Academy of Management Journal, 49(4), pp.633-642. Available at: http://dx.doi.org/10.5465/ amj.2006.22083020.
Sue, V. M. \& Ritter, L. A., 2012. Conducting online surveys, SAGE publication, Thousand Oaks, SAGE publication, USA.

Tabachnick, B. G. \& Fidell, L. S., 2000. Using multivariate statistics, 4th edn, Harper Collins, New York.

Tashakkori, A. \& Creswell, J., 2007. Exploring the nature of research questions in mixed methods research. Journal of mixed method research, 1(3), pp.207-211. Available at: https://doi.org/10.1177/1558689807302814.

Tashakkori, A. \& Teddlie, C., 2003. Issues and dilemmas in teaching research methods courses in social and behavioural sciences: US perspective. International Journal of Social Research Methodology, 6(1), pp.61-77. Available at: http://dx.doi. org/10.1080/13645570305055.

Tashakkori, A. \& Teddlie, C., 2010. Putting the human back in "Human research methodology": The researcher in mixed methods research. Journal of Mixed Methods Research, 4(4), pp.271-277. Available at: https://doi. org/10.1177/1558689810382532.

Tutty, L.M., 1996. Post-shelter services: The efficacy of follow-up programs for abused women. Research on Social Work Practice, 6(4), pp.425-441. Available at: https://doi.org/10.1177/104973159600600402.

Veenstra, A., Zuidwijk, R. and Van Asperen, E., 2012. The extended gate concept for container terminals: Expanding the notion of dry ports. Maritime Economics \& Logistics, 14(1), pp.14-32. Available at: https://doi.org/10.1057/mel.2011.15.

Wei, J., Sun, A. and Zhuang, J., 2010. The selection of dry port location with the method of Fuzzy-ANP. In Advances in Wireless Networks and Information Systems, pp.265-273. Springer, Berlin, Heidelberg. Available at: https://doi.org/10.1007/9783-642-14350-2 33

Williams, B., Onsman, A. and Brown, T., 2010. Australian paramedic graduate attributes: A pilot study using exploratory factor analysis. Emergency Medicine Journal, 27(10), pp.794-799. Available at: https://doi.org/10.1136/emj.2010.091751.

Wilkinson, M. J. \& Thornton, J. G., 1999. When is a research gift an inducement? Bulletin of Medical Ethics, 151, p. 2.

Woo, S.H., Bang, H.S., Martin, S. \& Li, K.X., 2013. Evolution of research themes in maritime policy and management. Maritime Policy and Management, 40(3), pp. 200-225. Available at: https://doi.org/10.1080/03088839.2013.788840.

Zikmund, W. G., Babin, B. J., Carr, J. C. \& Griffin, M., 2010. Business research methods, 8th edn, South-Western Cengage Learning, Mason, USA 